\title{
Implementasi Penggunaan Google Classroom dalam Mata Kuliah PAI Pada Masa Covid-19
}

\author{
Ahmad Nurfadel ${ }^{1}$, Wirdati ${ }^{2}$ \\ ahmadnurfadel98@gmail.com ${ }^{1}$,wirdati@fis.unp.ac.id ${ }^{2}$ \\ Universitas Negeri Padang1,2
}

\begin{tabular}{l}
\hline ARTICLE INFO \\
\hline Article history: \\
Received, 27 Oktober 2021 \\
Revised, 18 November \\
2021 \\
Accepted, 28 Februari \\
2022 \\
\hline
\end{tabular}

Keywords:

Implementasi, Google

Classroom, PAI, Pandemi

Covid-19

\section{Conflict of Interest:}

None

\section{Funding:}

None

\begin{abstract}
The online learning of the lecturers at the campus has determined the applications used in conducting online learning, such as the Google Classroom application used in Islamic Religious Education courses, Google Classroom is used as an online learning solution during the Covid-19 period. The purpose of the study was to determine the use planning, implementation, and evaluation results of the use of Google Classroom as an online learning tool during the Covid-19 pandemic in the Islamic Religious Education course at Tamansiswa Padang University. The research method is qualitative with a case study descriptive approach. The results of the study, based on observations made about the evaluation of plans that have been prepared by lecturers in conducting lectures using the Google Classroom application, are currently said to be successful because this media is very helpful in planning learning in one semester. The conclusion of this research is that in planning the lecturers in carrying out these online learning activities, the lecturer prepares RPS for the tasks given later and also prepares video tutorials, for the media used.
\end{abstract}

Corresponding Author: Ahmad Nurfadel, Department Islamic Education Faculty of Social Science Universitas Negeri Padang, Indonesia, Email: ahmadnurfadel98@gmail.com, Phone No: +6282171342649

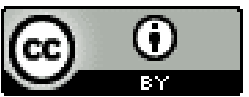

Copyright@2022, Author(s)

\section{Pendahuluan}

Pendidikan merupakan upaya yang dapat mempercepat pengembangan potensi manusia untuk mampu mengemban tugas yang dibebankan padanya, karena hanya manusia yang dapat dididik dan mendidik (Sa'ud dan Makmun, 2011). Kajian pendidikan yang perlu dikembangkan tersebut tentunya baik secara teoritis, praktis maupun secara filosofis. Teori dan praktik dalam dunia pendidikan mengalami perkembangan seiring dengan semakin meningkatnya peradaban manusia (Aedi, 2015).

Menurut Asih (2020) bahwa ahli teori pendidikan sering menyebut pendidikan era revolusi industri 4.0 untuk menggambarkan berbagai cara mengintegrasikan teknologi cyber baik secara fisik maupun non fisik dalam pembelajaran. Pendidikan era revolusi 
Ahmad Nurfadel dan Wirdati: Implementasi Penggunaan Google Classroom .......

industri 4.0 adalah fenomena yang merespons kebutuhan revolusi industri dengan penyesuaian kurikulum baru sesuai situasi saat ini.Kurikulum tersebut mampu membuka jendela dunia melalui genggaman contohnya memanfaatkan internet of things (IOT). Di sisi lain pengajar juga memperoleh lebih banyak refrensi dan metode pengajaran. Indonesia saat ini tengah dihadapkan dengan tantangan di tengah pandemi Covid-19, di mana pemerintah diharapkan mengatasi masalah tersebut dan masyarakat Indonesia dihimbau untuk di rumah saja. Pandemi Covid-19 ini tidak hanya mempengaruhi sektor ekonomi dan sosial, melainkan juga sektor pendidikan yang kini mau tidak mau harus mulai beradaptasi dengan era ini.

Kegiatan pembelajaran yang semula dilakukan secara tatap muka beralih menjadi pembelajaran non tatap muka. Program tersebut dikenal dengan pembelajaran daring atau sistem e-learning atau online learning. Menurut Hasibuan (2019), pembelajaran daring merupakan salah satu cara menanggulangi masalah pendidikan tentang penyelenggaraan pembelajaran. Defenisi pembelajaran daring adalah metode belajar yang menggunakan model interaktif berbasis internet dan learning manajemen sistem. Daring dalam Kamus Besar Bahasa Indonesia (KBBI) berarti dalam jaringan, terhubung melalui jejaring komputer, internet. Jadi pembelajaran daring merupakan sebuah upaya membelajarkan siswa yang dilakukan tanpa tatap muka dengan melalui jaringan/internet yang telah tersedia.

Universitas Tamansiswa merupakan salah satu Perguruan Tinggi di Kota Padang yang telah memanfaatkan e-Learning sebagai media pembelajaran pada kondisi saat ini yaitu adanya Covid-19. Kegiatan pembelajaran di kampus tersebut menggunakan media e-learning dengan memanfaatkan aplikasi Google Classroom. Dalam proses pembelajarannya mahasiswa diberikan penugasan oleh dosen dan mengirim hasilnya ke aplikasi tersebut. Selain itu, mahasiswa juga diberikan materi pelajaran melalui aplikasi Google Classroom. Universitas Tamansiswa ini sudah melakukan pembelajaran daring dimulai pada bulan Februari 2020 tahun ajaran 2019/2020 disebabkan oleh pandemi covid-19. Universitas Tamansiswa mempunyai e-learning resmi yaitu siadak akan tetapi para dosen lebih memilih aplikasi Google Classroom saat pandemi covid19.

Berdasarkan hasil wawancara pada tanggal 25 Februari 2021 dengan dosen mata kuliah Pendidikan Agama Islam di Universitas Tamansiswa Padang. Saat awal diumumkannya pembelajaran daring, para dosen di kampus tersebut telah menentukan aplikasi yang digunakan dalam melakukan pembelajaran daring, seperti aplikasi Google Classroom yang digunakan dalam mata kuliah Pendidikan Agama Islam, Google Classroom dijadikan solusi pembelajaran daring di masa covid-19. Persiapan pertama yang dilakukan rektor dan staff lainnya dengan membekali para dosen di Universitas Tamansiswa karena tidak semua dosen bisa memanfaatkan aplikasi Google Classroom tersebut.

Tujuan Penelitian adalah untuk (1) Mengetahui perencanaan penggunaan Google Classroom sebagai sarana pembelajaran daring masa pandemi Covid-19 dalam mata kuliah Pendidikan Agama Islam di Universitas Tamansiswa Padang. (2) Mengetahui pelaksanaan penggunaan Google Classroom sebagaisarana pembelajaran daring masa pandemi Covid-19 dalam mata kuliah Pendidikan Agama Islam di Universitas Tamansiswa Padang. (3) Mengetahui hasil evaluasi penggunaan Google Classroom sebagai sarana pembelajaran daring masa pandemi Covid-19 dalam mata kuliah Pendidikan Agama Islam di Universitas Tamansiswa Padang. Berdasarkan uraian 
tersebut, peneliti menemukan beberapa masalah yaitu dimulai dari apakah Universitas Tamansiswa tidak menggunakan platform elearning yang ada, penggunaan dari Google Classroom tersebut, pelaksanaan Google Classroom, dan hasil evaluasi penggunaan Google Classroom.

\section{Tinjauan Pustaka}

Pengertian Pendidikan Agama Islam Menurut (Hawi, 2013), Pendidikan Agama Islam adalah usaha sadar untuk menyiapkan siswa dalam menyakini, memahami, menghayati dan mengamalkan agama Islam melalui kegiatan bimbingan, pengarahan atau latihan dengan memerhatikan tuntunan untuk menghormati agama lain dalam hubungan kerukunan antar umat beragama dalam masyarakat untuk mewujudkan kesatuan nasional. Tujuan Pendidikan Agama Islam Menurut (Hawi, 2013), Pendidikan Agama Islam bertujuan untuk membentuk pribadi manusia menjadi pribadi yang mencerminkan ajaran-ajaran Islam dan bertakwa kepada Allah, atau tujuan pendidikan Islam adalah terbentuknya insan kamil. Menurut (Arifin, 2010), menyebutkan tujuan pendidikan agama islam adalah untuk menyuplai peserta didik agar dapat menjalankan peranan yang menuntut pengetahuan tentang ajaran agama Islam.

Fungsi pendidikan agama Islam bertujuan untuk meningkatkan keimanan, pemahaman, penghayatan, dan pengamalan siswa tentang agama Islam sehingga menjadi manusia Muslim yang beriman dan bertakwa kepada Allah Swt. Serta berakhlak mulia dalam kehidupan pribadi, bermasyarakat, berbangsa dan bernegara (Hawi, 2013). Pendidikan Agama Islam di Perguruan Tinggi memainkan peran penting dalam membinaulama berbakat memiliki kematangan emosi dan spritual berdasarkan agama. Di era globalisasi kematangan emosi dan spritual menjadi modal untuk menghadapi dinamika masyarakat berubah dengan cepat untuk membebaskan diri anda dari pemahaman radikal dan destruktif membutuhkan kedewasaan emosional dan spritual lain.

Kursus pendidikan agama Islam dipertimbangkan sistem pendidikan universitas negeri.Jadi lakukan segala upaya peningkatan mutu pendidikan tidak terlepas dari peningkatan kursus.Penguatan mata pelajaran pendidikan agama Islam saat ini memang menjadi prioritas utama, pertimbangan perkembangan ilmu pengetahuan dan teknologi serta arus informasi sedemikian cepatnya.Dalam kerangka inilah, penguatan kurikulum pendidikan agama Islam tersebut memberikan alternatif untuk meningkatkan mutu kualitas pribadi peserta didik (Aziz, 2011).

Pengertian Google Classroom, Gunawan dan Sunarman (dalam Rahmanto \& Bunyamin 2020) memaparkan Google Classroom jika didefenisikan ke dalam bahasa Indonesia berarti google Kelas yaitu sebuah beranda pembelajaran dalam dunia pendidikan yang digunakan untuk media yang membantu proses pembelajaran dalam hal penugasan dengan format paperless (tanpa kertas). Fungsi Google Classroom Di website Google Classroomjuga tertulis informasi yang terhubung ke semua layanan Google for Education lainnya, sehingga pendidik dapat menggunakan Google mail, Google Drive, Google Calendar, Google Docs, Google Sheets, Google Slides, dan Google di situs Google, Situs web. Proses pembelajaran dengan cara ini, ketika pendidik menggunakan Google Classroom, pendidik juga dapat menggunakan Google Calendar untuk mengingatkan siswa tentang jadwal atau tugas yang ada, dan menggunakan Google drive sebagai tempat untuk menyimpan kebutuhan belajar seperti, power 
Ahmad Nurfadel dan Wirdati: Implementasi Penggunaan Google Classroom .......

point, yang perlu ada dalam dokumen pembelajaran yang digunakan. Oleh karena itu, Google kelas dapat membantu pengajar dan siswa untuk melakukan aktivitas belajar mengajar yang lebih mendalam dan lebih mudah (Faizah,2020).

Cara menggunakan Google Classroom Dalam memulai Google Classroom kita terlebih dahulu masuk akun google lalu mencari produk google tersebut, selanjutnya masuk dalam akun Google Classroom kita dihadapkan 3 sajian menu yaitu, stream (genre), classwork (kegiatan murid), dan people (orang). Stream merupakan fasilitas google groub buat menciptakan pengumuman, mendiskusikan gagasan, atau melihat bagaimana aliran tugas, materi, dan quiz berdasarkan topik-topik yang diajarkan pendidik.

Kelebihan Google Classroom Iftakhar (dalam Maharani \& Kartini, 2019) menyebutkan bahwa ada beberapa kelebihan dari Google Classroom yaitu mudah dalam penggunaannya, hemat waktu, fleksibel, gratis dan berbasis cloud. Fitur dalam Google Classroom telah disediakan menu bagi pendidik untuk mendonload materi, baik berbentuk microsoft word maupun jenis file lainnya. Kelemahan Google Classroom yaitu tampilan yang dimiliki kurang menarik hanya menampilkan beberapa gambar dan itu hanya berupa gambar cartoon. Google Classroom sebaiknya menambah gambar lagi supaya menarik bagi peserta didik agar peserta didik tidak merasa bosan. Masalah tampilan sangat wajar membuat orang bingung, ada yang suka dan ada yang tidak suka tergantung selera orang yang menggunakan Google Classroom tersebut (Wijoyo \& dkk, 2021).

Media pembelajaran menurut (Surayya, 2012), media pembelajaran adalah alat yang mampu membantu proses belajar mengajar serta berfungsi untuk memperjelas makna informasi yang disampaikan, sehingga dapat mencapai tujuan pembelajaran yang telah direncanakan sebelumnya.Menurut (Azhar, 2011), media pembelajaran yaitu alat bantu untuk proses belajar baik di dalam maupun di luar kelas, sehingga komponen sumber belajar yang mengandung materi intruksional di lingkungan siswa yang dapat merangsang peserta didik untuk belajar.

Metode pembelajaran menurut (Iskandarwassid dan Sunendar, 2011), metode pembelajaran adalah cara kerja yang sistematis untuk memudahkan pelaksanaan berbagai kegiatan pembelajaran untuk mencapai tujuan pembelajaran yang diinginkan. Tujuan Pembelajaran Menurut (Daryanto, 2005), tujuan pembelajaran adalah tujuan yang menggambarkan pengetahuan, kemampuan, keterampilan, dan sikap yang harus dimiliki peserta didik sebagai akibat dari hasil pembelajaran yang dinyatakan dalam bentuk tingkah laku. Menurut (Hamalik, 2005), tujuan pembelajaran yaitu suatu deskripsi mengenai tingkah laku yang diharapkan tercapai oleh peserta didik setelah selesainya pembelajaran.

Masa pandemi Covid-19 menurut (Sebayang, 2020), Badan Kesehatan Dunia atau WHO (World Health Organization) dimulai dari Januari 2020 telah mengungkapkan bahwa dunia telah darurat global terkait virus yang diesebabkan oleh penyebaran coronavirus (Covid-19). Termasuk di Indonesia hal tersebut berdampak besar pada berbagai sektor, salah satunya bidang pendidikan. Sebuah fenomena luar biasa yang terjadi di bumi pada abad ke-21, skalanya mungkin sebanding dengan Perang Dunia II karena skala besar (seperti kompetisi olahraga Internasional) hampir seluruhnya 
ditunda ataupun dibatalkan. Situasi ini hanya terjadi pada Perang Dunia II dan tidak pernah ada situasi lain yang dapat membatalkan peristiwa tersebut.

\section{Metode}

Alasan peneliti menggunakan metode deskriptif studi kasus adalah untuk mengetahui, memahami kasus, dan menetapkan masalah yang ada pada penggunaan Google Classroom sebagai sarana pembelajaran daring terhadap mata kuliah Pendidikan Agama Islam di Universitas Tamansiswa Padang. Menurut Sugiyono (2012), informan dalam penelitian kualitatif ditentukan melalui purposive sampling, yaitu pengambilan data dengan kriteria tertentu yaitu orang yang dianggap berpengaruh dan bisa memberikan informasi terkait suatu fenomena sehingga memudahkan peneliti dalam melakukan penelitian. Sehubungan dengan itu yang menjadi informan dalam penelitian ini adalah ketua jurusan yang ada di Universitas Tamansiswa, dosen yang terkait dengan Pendidikan Agama Islam, mahasiswa semester 1 fakultas hukum yang menggunakan Google Classroom. Adapun alasan penulis memilih informan tersebut adalah karena dapat memberikan gambaran dan informasi yang sesuai dengan tujuan penelitian.

Pada penelitian kualitatif penelitilah yang menjadi instrumen kunci atau yang bisa disebut dengan alat penelitian sehingga manusia sebagai instrumenpenelitian berfungsi untuk menentukan fokus penelitian, memilih informan untuk sumber data, mengumpulkan data, menilai kualitas data, analisis data, melakukan penafsiran terhadap data-data yang diperoleh dan merumuskan kesimpulan (Sugiyono, 2019). Teknik pengumpulan data yang peneliti gunakan dalam penelitian ini adalah sebagai berikut: Observasi, Wawancara dan Dokumentasi.

Teknik Analisis data, Miles dan Hubberman (dalam Sugiyono, 2019), Diyakini bahwa kegiatan analisis data kualitatif dilakukan pada saat pengumpulan data terjadi, dan setelah pengumpulan data selesai, bersifat interaktif dan terus terjadi sampai selesai, sehingga data menjadi jenuh. Analisis data dilakukan dalam beberapa aktivitas yaitu sebagai berikut: Reduksi data, Penyajian data dan Verifikasi data. Teknik Keabsahan Data digunakan untuk memastikan data yang diperoleh dari hasil penelitian adalah data yang valid atau dapat dipercaya. Menurut Moleong (2009), ada empat cara uji keabsahan data yaitu kepercayaan (Kredibilitas), keteralihan (Transferabilitas), kebergantungan (Dependabilitas), ketegasan (Konfirmabilitas). Dalam menguji keabsahan data pada penelitian ini menggunakan teknik kredibilitas (kepercayaan). Untuk menguji kredibilitas suatu data ada beberapa cara salah satunya trianggulasi. Trianggulasi adalah suatu cara dalam memeriksa keabsahan data yang menggunakan sesuatu yang lain seperti teknik, sumber dan waktu (Moleong, 2009). Trianggulasi sumber yaitu pengecekkan keabsahan data melalui berbagai sumber. Pada penelitian ini informasi yang peneliti dapat tidak hanya dari dosen PAI tetapi dari informan lain yang bisa memberikan informasi tentang penelitian ini seperti mahasiswa dan staf kampus tersebut. Trianggulasi teknik adalah suatu cara untuk menguji keabsahan data melalui sumber yang sama namun penggunaan metode atau teknik yang berbeda. Pada penelitian ini peneliti menggunakan teknik wawancara, observasi dan dokumentasi.

\section{Hasil dan Pembahasan}

Perencanaan penggunaan Google Classroom sebagai sarana pembelajaran daring masa pandemi Covid-19 dalam mata kuliah Pendidikan Agama Islam 
Ahmad Nurfadel dan Wirdati: Implementasi Penggunaan Google Classroom ......

Dalam pembelajaran ada sebuah perencanaan, pelaksanaan dan evaluasi. Tahap pertama sebelum proses pembelajaran adalah perencanaan yang dilakukan oleh pendidik. Perencanaan adalah sebuah proses dimana terdapat suatu kegiatan dalam menentukan konsep pembelajaran agar terlaksana dengan sistematis. Pada tahap perencanaan ini biasanya dalam pembelajaran ada istilahnya RPP (Rencana Proses Pembelajaran). RPP ini dirancang oleh pendidik pada jenjang sekolah sedangkan untuk tingkat universitas dikenal istilah RPS (Rencana Pembelajaran Semester). Adapun tujuan dari penetapan perencanaan ini adalah untuk sebagai acuan bagi pendidik baik itu guru ataupun dosen agar memudahkannya dalam memperoleh gambaran proses pembelajaran yang akan berlangsung supaya bisa terlaksana sesuai dengan tujuan yang dinginkan.

Berdasarkan hasil wawancara peneliti dengan informan di Universitas Tamansiswa, mengenai proses perencanaan dalam implementasi penggunaan Google Classroom pada mata kuliah PAI Bapak Joni Zulhendra selaku dosen yang mengampu mata kuliah PAI menyatakan bahwa:

"Kalau dalam penggunaan Google Classroom sebenarnya tidak ada di rencana pembelajaran, tetapi karena pandemi covid-19 ini maka aplikasi Google Classroom itu digunakan. Jadi dalam RPS tidak ada dibunyikan tetapi media yang digunakan salah satunya Google Classroom.". (Wawancara Joni Zulhendra S.H.I, MA 28 September 2021).

Hal senada juga disampaikan oleh informan lainnya, yaitu Bapak Agus Hermanto beliau mengatakan bahwa: "Biasanya untuk proses pembelajaran ini langkah awalnya tentu dengan menyiapkan RPS karena proses pembelajaran yang dilaksnaakan tersebut tergambar dalam RPS". (Wawancara Agus Hermanto S.HI., MA. 29 September 2021).

Perkembangan dalam dunia pendidikan banyak memberikan kemudahan contohnya pembelajaran yang tidak harus dilaksanakan di dalam kelas secara langsung atau tatap muka, tetapi bisa dilaksanakan secara online atau daring dengan menggunakan berbagai model dan media pembelajaran yang mendukung.Seperti pada saat ini dimasa pandemi Covid-19 yang berdampak pada seluruh aktivitas kehidupan manusia dikarenakan adanya pembatasan interaksi antar manusia untuk memutus rantai penyebarangan virus Corona.Untuk itu sistem pembelajaranpun juga berubah dari tatap muka menjadi online.

Pembelajaran online atau daring yang dilaksanakan di Universitas Tamansiswa Padang pada mata kuliah Pendidikan Agama Islam di masa Pandemi Covid-19 menggunakan salah satu sarana pembelajaran yaitu Google Classroom. Hal ini berdasarkan dari hasil wawancara dengan informan yaitu dosen yang mengampu mata kuliah Pendidikan Agama Islam yang bernama Bapak Joni Zulhendra yang menyatakan bahwa: "Dalam pembelajaran daring yang dilakukan pada mata kuliah Pendidikan Agama Islam Universitas Tamansiswa memanfaatkan media yang digunakan untuk memberikan materi pembelajaran yaitu berupa video maupun ppt yang berbentuk materi pembelajaran". (Wawancara Joni Zulhendra S.HI., MA, 28 September 2021).

Hal yang sama juga dinyatakan oleh informan lain yang juga merupakan dosen yang mengajar pada mata kuliah Pendidikan Agama Islam yaitu Bapak Agus Hermanto S.H.I, MA yang mengatakan bahwa: "Dalam pembelajaran daring kami menggunakan Google Classroom media yang diberikan yaitu video maupun youtube tentang materi pembelajaran dan Siadak Unitas ini jarang digunakan karena penggunaannya yang 
rumit dilakukan oleh mahasiswa". (Wawancara Agus Hermanto S.HI., MA. 29 September 2021).

Berdasarkan paparan di atas dapat disimpulkan bahwa dosenTerkait dalam melaksanakan proses pembelajaran tentunya dibutuhkan untuk merancang RPS. Untuk RPS yang dibuat dosen pada saat pembelajaran daring sebenarnya hampir sama dengan RPS pada pembelajaran tatap muka. Perbedaannya hanya pada konsep dan media yang akan digunakan pada proses pembelajaran serta biasanya pada pembelajaran tatap muka penugasan lebih sedikit sedangkan untuk pembelajaran online ini penugasan lebih banyak.

Selain membuat RPS dalam perencanaan ini juga dibutuhkan persiapan dari dosen dalam hal keterampilan menggunakan aplikasi Google Classroom ini karena dalam aplikasi ini akan ada menu untuk menyajikan materi, melakukan absensi, penugasan dan sebagainya. Seperti yang disampaikan oleh Bapak Joni Zulhendra bahwa: "Dalam aplikasi Google Classroom ini yang jelas ada menu classwork untuk mengupload tugas mahasiswa kemudian absensi mahasiswa dan bisa dilihat langsung nilai-nilai, tugastugas mahasiswa". (Wawancara Joni Zulhendra S.HI., M.A, 28 September 2021).

Untuk perencanaan selanjutnya yaitu menyiapkan media pembelajaran yang akan digunakan dalam pembelajaran dengan menggunakan Google Classroom seperti tampilan materi yang akan digunakan, yang berbentuk ppt, pdf dan sebagainya. Seperti yang disampaikan bapak Joni Zulhendra S.HI., MA. yang menyatakan bahwa: "Dalam pembelajaran nantinya saya mengirim materi melalui PPT atau PDF, lalu di akhir materi tersebut saya memberikan tugas harian". (Wawancara Joni Zulhendra S.HI., MA. 28 September 2021).

Berdasarkan hasil observasi selanjutnya tentang metode yang direncanakan dalam mengajar yaitu seperti metode tanya jawab maupun metode yang lainnya seperti halnya yang disampaikan oleh bapak Agus Hermanto S.HI., MA. sebagai berikut: "Metode yang digunakan tanya jawab dan dosen menerangkan pembelajaran berbentuk pemberitahuan yang ada di aplikasi Google Classroom, setelah itu dosen menyampaikan tata cara penggunaan Google Classroom atau di pertemuan pertama perkuliahan." (Wawancara Agus Hermanto SHI,.MA 29 September 2021).

Dari paparan di atas bisa disimpulkan bahwa dalam pembelajaran daring dengan menggunakan Google Classroom untuk tahap perencanaan dosen menyiapkan RPS yang dijadikan sebagai pedoman dalam mengajar, keterampilan dalam menggunakan aplikasi Google Classroom, menyiapkan media yang akan digunakan dalam proses pembelajaran seperti ppt dan sebagainya, dan juga metode yang direncanakan seperti metode tanya jawab dan sebagainya.

\section{Pelaksanaan penggunaan Google Classroom sebagai saranapembelajaran daring masa pandemi Covid-19 dalam mata kuliah Pendidikan Agama Islam}

Kecocokan RPS dengan proses pembelajaran dmelakukan penelitian, peneliti melakukan observasi terhadap aktivitas pembelajaran daring melalui Google Classroom dan wawancara dengan dosen dan mahasiswa di kampus. Diketahui dari hasil observasi dan wawancara implementasi penggunaan Google Classroom dalam pembelajaran daring pada masa pandemi Covid-19 di Univesritas Tamansiswa Padang sudah efektif dilaksanakan terkait dengan rencana yang telah dilakukan. Untuk melaksanakan penggunaan Google Classroom, digunakan untuk kegiatan belajar 
Ahmad Nurfadel dan Wirdati: Implementasi Penggunaan Google Classroom ......

mengajar, yaitu: satu minggu sekali. Mengenai hal-hal yang harus disiapkan dosen yaitu: Berdasarkan hasil observasi kondisi pelaksanaan penggunaan pembelajaran daring pada masa pandemi Covid-19 yaitu dalam persiapan dosen dan hasil pembelajaran pengamatan yang dilakukan peneliti pada persiapan dosen, terlihat bahwa dosen mulai belajar tepat waktu menunjukkan bahwa dosen telah mempersiapkan pelajaran, dosen juga telah menyiapkan materi untuk disampaikan kepada mahasiswa.

Pertama dosen manyampaikan materi pembelajaran yang disampaikan melalui aplikasi Google Classroom, kondisi penerapan penggunaan Google Classroom pada pembelajaran daring di masa pandemi Covid-19 tidak jauh berbeda dengan pembelajaran di kelas. Selama proses pembelajaran, diketahui bahwa dosen menggunakan Google Classroom untuk media pembelajaran daring dan saat memberikan materi, dosen mengirimkan informasi atau materi microsoft powerpoint ke magnet di ruang Google Classroom. Google Classroom sebagai salah satu dari media pembelajaran untuk melakukan kegiatan pembelajaran, termasuk untuk memberikan materi selama pandemi Covid-19 saat ini.

Berdasarkan wawancara yang dilakukan peneliti dengan bapak Joni Zulhendra S.HI., MA. mengenai penyampaian materi adalah sebagai berikut: "Penyampain materi lewat aplikasi Google Classroom ini disampaikan melalui menu utama yang ada di Google Classroom, informasi terkait materi, kemudian ada tugas-tugas yang bisa di upload mahasiswa". (Wawancara 28 September 2021).

Berdasarkan paparan di atas dapat disimpulkan bahwa pembelajaran Google Classroom masa pandemi Covid-19 dalam penyampaian materinya dosen sudah menyampaikan materinya dengan jelas. Pastinya dalam melaksanakan pembelajaran daring pada masa pandemi Covid-19 ini, jaringan internet yang stabil merupakan sistem yang dapat mempermudah dosen dalam menyampaikan informasi atau menyampaikan materi pembelajaran.

Kedua, media pembelajaran, kita sudah mengetahui bahwa media pembelajaran memegang peranan yang sangat penting dalam melaksanakan kegiatan pembelajaran. Karena melalui penggunaan media pembelajaran akan lebih mudah bagi mahasiswa untuk memahami materi jika didukung oleh media tersebut.

Menurut pengamatan dari pelajaran dengan Google Classroom, dosen menggunakan gambar, video, dan seringkali materi yang menggunakan powerpoint (PPT) saat menggunakan Google Classroom untuk pembelajaran daring.Hal tersebut sesuai dengan wawancara yang dilakukan peneliti dengan bapak Agus Hermanto S.HI., MA. tentang media pembelajaran adalah sebagai berikut: "Media yang digunakan yang pertama ada Google Classroom jadi aplikasi ini media yang cukup mudah digunakan karena aplikasi di dalamnya itu ada menu-menu untuk tugas mahasiswa kemudian bahan-bahan materi perkuliahan dan absensi mahasiswa bisa di ambil di Google Classroom tersebut. Yang kedua bapak menggunakan video pembelajaran, gambar yang sesuai maupun PPT untuk menyampaikan materinya". (Wawancara 29 September 2021).

Pendapat tersebut juga sama dengan mahasiswi yang bernama Mardiah Ermawati yang dilakukan peneliti melalui wawancara adalah sebagai berikut: "iya dosen menggunakan media seperti powert point, pdf, dan video berbentuk materi pembelajaran" (Wawancara 30 September 2021). 
Berdasarkan paparan di atas dapat disimpulkan bahwa dalam pembelajaran daring masa pandemi Covid-19 ini, bahwa pelaksanaan pembelajarannya sangat membutuhkan media pembelajaran untuk membantu mahasiswa dalam pembelajaran.

Ketiga, strategi mengajar dosen dalam mengajar dengan menggunakan Google Classroom yaitu dosen menyampaikan materi pertama dengan memberikan pemahaman tentang Google Classroom agar mahasiswa mudah dalam menggunakan Google Classroom dan dosen memberitahukan bahwa pembelajaran akan dilakukan dengan menggunakan Google Classroom.Hal tersebut sesuai dengan hasil wawancara peneliti dengan bapak Joni Zulhendra S.HI., MA. adalah sebagai berikut: "Strategi yang pertama mahasiswa diberikan dulu pemahaman terhadap media pembelajaran setelah mahasiswa paham akan media pembelajaran salah satunya Google Classroom maka mahasiswa akan mudah menggunakan aplikasi Google Classroom, yang kedua saya memberikan informasi atau pemberitahuan bahwa pembelajaran akan dilaksanakan dalam waktu yang ditentukan seperti pembelajarannya saya mengirim materi melalui ppt atau pdf lalu di akhir materi tersebut saya memberikan tugas harian." (Wawancara 28 September 2021).

Berdasarkan paparan di atas dapat disimpulkan bahwa strategi yang bapak lakukan dalam pembelajaran menggunakan Google Classroom sebenarnya harus mengetahui atau memahami tentang penggunaan aplikasi Google Classroom dalam pembelajaran daring masa pandemi Covid-19.

Keempat, untuk memaksimalkan pembelajaran daring dengan menggunakan Google Classroom yaitu pada pembelajaran ini alhamdulillah di kampus untuk dosen dan mahasiswa sebelum memulai pembelajaran menggunakan whatssap groub untuk saling berinteraksi, supaya tidak terjadi miss communication antara dosen dan mahasiswa. Faktor penghambat merupakan suatu hal yang menghambat jalannya suatu kegiatan atau menggagalkan.Seperti halnya dalam menggunakan Google Classroom tentunya ada beberapa faktor penghambatnya dalam aplikasi tersebut.

Seperti hal tersebut sesuai dengan hasil wawancara peneliti dengan Bapak Agus Hermanto adalah sebagai berikut: "Faktor penghambatnya adalah faktor dari mahasiswa itu sendiri misalnya paket internet yang tidak ada, mahasiswa ini ragu dalam menggunakan Google Classroom atau mahasiswa ini gaptek (gagap teknologi) karena baru semester 1. Kemudian faktornya terkadang mahasiswa lalai dalam perkuliahan atau ketiduran dalam perkuliahan sehingga mereka tidak membuat tugas maupun mengambil absen." (Wawancara 29 September 2021).

Pendapat tersebut juga sama dengan mahasiswa yang bernama Fauzan Putra yang dilakukan peneliti melalui wawancara adalah sebagai berikut: "Kendalanya seperti jaringan yang tidak stabil, terkadang paket data yang habis sebelum perkuliahan dan kendala dari diri sendiri terkadang lupa bahwa hari itu ada perkuliahan di Google Classroom." (Wawancara 30 September 2021).

Berdasarkan paparan di atas dapat disimpulkan bahwa faktor penghambat dari penggunaan Google Classroom terletak pada jaringan yang kurang stabil maupun faktor internal dari mahasiswa tersebut yang lalai dalam perkuliahan.

Dalam sajian menu-menu yang ada di Google Classroom tentunya ada menu yang digunakan dosen seperti memberikan informasi maupun memberikan tugas menumenu tersebut ialah stream, classwork dan people. Stream digunakan untuk melihat 
Ahmad Nurfadel dan Wirdati: Implementasi Penggunaan Google Classroom ......

bagaimana aliran tugas, materi, dan quiz. Classwork ini bisa dipakai pendidik untuk menciptakan soal tes, pretes, quiz, mengunggah materi dan mengadakan refleksi. Sedangkan people ialah orang yang menggunakan Google Classroom tersebut.

Hal tersebut digunakan dosen dalam menggunakan Google Classroom ini dijelaskan dalam wawancara peneliti dengan bapak Joni Zulhendra adalah sebagai berikut: "Ya saya selalu mengisi stream karena saya sering memberikan pemberitahuan atau informasi terkait melalui strem tersebut, selanjutnya pada menu classwork saya selalu memberikan bahan-bahan materi perkuliahan yang saya upload lalu dalam menu classwork mahasiswa tinggal mendownload dan melihat apa yang di instruksikan dosen." (Wawancara 28 September 2021).

Pendapat selanjutnya tentang stream dan classwork ini dijelaskan dalam wawancara peneliti dengan bapak Agus Hermanto S.Hi MA adalah sebagai berikut:"ya dosen mengadakan ujian tengah semester menggunakan menu di Google Classroom kemudian ujian akhir karena disana sudah disediakan menu-menu untuk melakukan ujian tersebut. Ujian ini dilakukan 2 kali dalam 1 semester yaitu ujian mid dan ujian akhir semester." (Wawancara Agus Hermanto S.HI., MA. 29 September 2021). Berdasarkan paparan di atas dapat disimpulkan bahwa menu-menu yang digunakan dalam penggunaan Google Classroom seperti stream dan classwork selalu digunakan dosen untuk membantu memudahkan dosen dalam memberikan materi dan memberikan informasi kepada mahasiswa.

\section{Evaluasi penggunaan Google Classroom sebagai sarana pembelajaran daring masa pandemi Covid-19 dalam mata kuliah Pendidikan Agama Islam}

Sebagaimana diketahui bahwa evaluasi adalah suatu kegiatan yang dilakukan untuk mengukur sejauh mana hasil yang telah dicapai. Evaluasi dapat diartikan sebagai proses evaluasi berdasarkan kriteria, tujuan, atau tujuan tertentu yang telah ditetapkan. Selanjutnya, ditarik kesimpulan tentang apa yang di evaluasi indikator evaluasi penggunaan Google Classroom adalah evaluasi dari penggunaan aplikasi Google Classroom dan evaluasi hasil belajar mahasiswa.

Berdasarkan observasi yang dilakukan tentang implementasi penggunaan Google Classroom dalam mata kuliah pendidikan agama Islam pada masa pandemi Covid-19 di Universitas Tamansiswa Padang, terkait evaluasi dengan penggunaan aplikasi Google Classroom yang digunakan sebagai sarana pembelajaran daring. Untuk mengetahui tingkat dari aplikasi Google Classroom dan mengukur tingkat efektif atau tidaknya aplikasi Google Classroom, dari evaluasilah dapat diketahui bahwa aplikasi ini sudah berjalan lancar dalam pembelajaran daring maupun tidak berjalan lancar.

Hal ini berdasarkan dari hasil wawancara peneliti dengan bapak Joni Zulhendra S.HI., MA. yang mengatakan bahwa: "Untuk saat ini aplikasi Google Classroom sangat efektif di tamansiswa karena aplikasi ini sangat mudah digunakan, sehingga mahasiswa tidak sulit mengaplikasikannya. Kalau dibandingkan aplikasi lain seperti zoom yang pertama media pembelajaran zoom berbayar, kemudian paket data yang digunakan lebih besar dan zoom lebih berat di download bagi mahasiswa di hanphone. Kemudian siadak elearning resmi kampus lebih efektif untuk pengisian krs atau melihat nilai sistem perkuliahan ada juga yang menggunakan siadak tetapi bagi mahasiswa rumit digunakan." (Wawancara 28 September 2021). 
Pendapat tersebut juga sama dengan mahasiswa yang bernama Fauzan Putra yang dilakukan peneliti melalui wawancara adalah sebagai berikut: "Karena aplikasinya sangat mudah dan efektif dalam belajar apalagi tugasnya mudah diterapkan dalam Google Classroom, ditambah lagi proses pembelajarannya jadi lebih efesien, menghemat waktu dan tenaga." (Wawancara 30 September 2021).

Dari paparan di atas dapat disimpulkan bahwa dalam penggunaannya aplikasi Google Classroom sudah sangat efektif digunakan dalam pembelajaran daring karena penerapannya sangat mudah digunakan dan lebih flexsible.

Berdasarkan observasi yang dilakukan tentang evaluasi perencanaan yang telah disiapkan dosen dalam melakukan perkuliahan dengan menggunakan aplikasi Google Classroom untuk saat ini sudah dikatakan berhasil karena dengan media ini sangat membantu dalam merencanakan pembelajaran dalam 1 semester.

Hal ini berdasarkan dari hasil wawancara peneliti dengan bapak Agus Hermanto adalah sebagai berikut: "Untuk saat ini perencanaannya berhasil digunakan mahasiswa, karena dengan pembelajaran Google Classroom mahasiswa paham akan pembelajaran meskipun dalam keadaan daring." (Wawancara Agus Hermanto 29 September 2021). Pendapat tersebut juga sama dengan bapak Joni Zulhendra yang dilakukan peneliti melalui wawancara adalah sebagai berikut: "Dalam perencanaan menggunakan aplikasi ini sudah sangat berhasil karena dalam aplikasi Google Classroom sudah terlihat mana bagian tugas maupun bagian materi yang diberikan dosen yang telah dibuat di menu-menu Google Classroom." (Wawancara Joni Zulhendra 29 September 2021).

\section{Simpulan}

Kesimpulan paparan di atas dapat disimpulkan bahwa dalam perencanaannya Google Classroom sudah berhasil karena dengan sistem pembelajaran yang digunakan dosen di aplikasi Google Classroom membuat mahasiswa mudah paham akan penggunaan Google Classroom tersebut. Dosen dan mahasiswa tidak menemukan kesulitan apapun dalam proses pembelajaran dengan menggunakan aplikasi Google Classroom, ini terlihat dari hasil absensi dan hasil pembelajaran mahasiswa selama menggunakan aplikasi Google Classroom. Evaluasi dari pelaksanaan penggunaan Google Classroom sudah maksimal karena tidak adanya kesulitan mahasiswa dalam pelaksanaan Google Classroom dalam mengikuti perkuliahan khususnya mata kuliah PAI. Kelebihannya sangat mudah untuk menerima dan mengerjakan tugas yang diberikan, Materi yang diberikan juga secara rinci disertai gambar atau video yang disesuaikan dengan materi pelajaran. Dan juga kita bisa belajar dimana dan kapapun. Dan untuk kekurangan nya ia itu tidak bisa bertatap muka, dan juga tidak bisa praktek secara langsung, hanya saja siswa bisa praktek dengan di video in terus di kirim ke ruang Google Classroom. Kegiatan pembelajaran daring dapat dilihat dari absen mahasiswa dan melihat aliran tugas yang dikirim mahasiswa yang dikirim melalu Google Classroom, seperti tugas keagamaan praktek mengaji berupa video yang dikirim melalui Google Classroom.

Meskipun pandemi Covid-19, pembelajaran tetap dilaksanakan secara daring melalui penggunaan aplikasi yaitu Google Classroom, dan juga tidak menghalangi mahasiswa untuk terus belajar di rumah dan mendapatkan hasil yang memuaskan. Dengan diterapkannya penggunaan Google Classroom untuk pembelajaran daring di masa pandemi Covid-19, hasil dari nilai tugas dan nilai ujian mahasiswa menunjukkan bahwa hasil belajar yang dicapai setiap siswa sudah mencapai KKM. Oleh karena itu, 
Ahmad Nurfadel dan Wirdati: Implementasi Penggunaan Google Classroom .......

penerapan penggunaan Google Classroom dalam pembelajaran daring selama pandemi Covid-19 telah mencapai KKM, tujuan pembelajaran telah tercapai dengan baik dan pembelajaran daring dengan Google Classroom menjadi alternatif, pada masa pandemi Covid-19 di Universitas Tamansiswa Padang.

\section{Referensi}

Aedi, Nur. 2015. Dasar-dasar Manajemen Pendidikan. Yogyakarta:Gosyen Publishing.

Asih, Shintya Gugah. 2020. Pendidikan Era Revolusi Industri 4.0 di Tengah Covid-19 (Online). (https://ombudsman.go.id/artikel/r/artikel-pendidikan-era- revolusiindustri-40-di-tengah-covid-19diunduh pada tanggal 5januaril 2021 pada jam11.30 WIB).

Arifin, M, (2010). Filsafat Pendidikan Islam. Jakarta: Bumi Aksara.Arsyad, A. (2017). Media Pembelajaran. Jakarta: Rajawari Pers.

Aziz, Y. (2011). Penguatan Mata Kuliah Pendidikan Agama Islam Di Perguruan Tinggi Umum. JurnalSosial Humaniora, 4(2), 145-163

Faizah, (2020).Implementasi Aplikasi Google Classroom Dalam Pembelajaran Daring Matematika Masa Pandemi Covid-19 SMP Negeri 4 Salatiga. Skripsi, Salatiga: Jurusan Tadris Matematika IAIN Salatiga.

Hasibuan, MS \& Simarmata, Janner \& Sudirman, Acai. (2019). E-Learning: Implementasi, strategi dan inovasinya. Medan : Yayasan Kita Menulis.

Hawi, Akmal. (2013).Kompetensi Guru Pendidikan Agama Islam. Jakarta: PT Grafindo Persada.

Iskandar, dkk. 2020. Aplikasi pembelajaran TIK. Yayasan Kita Menulis (diakses pada tanggal 12 Juni 2021, pukul 00.30 WIB).

Moleong, L., J. (2009). Metode Penelitian Kualitatif, Bandung: Remaja Rosdakarya.

Maharani, \& Kartini, (2019).Penggunaan Google Classroom Sebagai Pengembangan Kelas Virtual Dalam Keterampilan Pemecahan Masalah Topik Kinematika Pada Mahasiswa Jurusan Sistem Komputer. Jurnal, Bali: STMIK STIKOM Indonesia.

Sa'ud, Udin Syaefudin dan Abin Syamsudin Makmun. 2011. Perencanaan Pendidikan. Bandung: Remaja Rosdakarya.

Sebayang, R. (2020, 12 Maret). WHO Nyatakan Wabah COVID 19 Jadi Pandemi Apa Maksudnya? CNBC Indonesia Diakses dari Sudaryono, (2018). Metode Penelitian, Jakarta: Rajagrafindo Persada.

Sugiyono, (2012).Metode Penelitian Pendidikan Pendekatan Kuantitatif, Kualitatif dan R\&D. Bandung: Alfabeta.

Sugiyono, (2019). Metode Penelitian dan Pengembangan: Resarch and Development/ R\&D, Bandung: Alfabeta. 